\section{Measuring economic sustainability: Are we doing it right?}

Sri Lanka Journal of Social Sciences and Humanities Volume 2 Issue 1, February 2022: 21-30 ISSN: 2773 692X (Online), 27736911 (Print) Copyright: (C) 2021 The Author(s)

Published by Faculty of Social Sciences and Languages, Sabaragamuwa University of Sri Lanka Website: https://www.sab.ac.lk/sljssh DOI: http://doi.org/10.4038/sljssh.v2i1.53

\author{
Tennakoon, W.D.N.S.M. ${ }^{1,{ }^{*}}$ and Janadari, M.P.N. ${ }^{2}$ \\ ${ }^{1}$ Faculty of Graduate Studies, University of Kelaniya, Kelaniya, 11600, Sri Lanka. \\ 2 Department of Human Resource Management, University of Kelaniya, Kelaniya, 11600, Sri Lanka.
}

Received: 15 June, 2021, Revised: 26 September, 2021, Accepted: 11 November, 2021.

How to Cite this Article: Tennakoon, W. D. N. S. M. \& Janadari, M. P. N. (2022). Measuring economic sustainability: Are we doing it right? Sri Lanka Journal of Social Sciences and Humanities, 2(1), 21-30.

\begin{abstract}
Economic sustainability, one among the Triple Bottom Lines (TBLs), perhaps the most attractive and popular dimension of sustainability, is the long-term standpoint of an establishment in terms of financial and marketing measures. The realization of the value of economic sustainability is a far-felt need for practitioners because of its sense of stability. Despite the theorists' immense contribution to offering a theoretically sought definition and workable measures, the concept remains ambiguous in its application. This review examined the evolution of economic sustainability as a construct in terms of its definitions and measures. A desk review of the published literature in leading journals was performed. Each contribution was assessed against the properties of available theoretical bases to unearth the theoretical lapses. Findings include research gaps and associated directions for future studies in bridging the identified gaps.
\end{abstract}

Keywords: Economic Sustainability, Sustainability

\section{INTRODUCTION}

The word "sustainability" is derived from the Latin sustinere (tenere, to hold; sus, up) (Jeronen, 2013). How sustainability is used nowadays is based on the English term "sustainability", which expresses the possibility of a certain matter to be supported. Sustainability is seen as a paradigm for thinking about the future in which environmental, societal, and economic considerations are balanced in the pursuit of improved quality of life. The ideals and principles behind it lie in concepts such as intergenerational equity, gender equity, social tolerance, poverty alleviation, environmental preservation and restoration, natural resource conservation, and building just and peaceful societies. The term is often used with the social entities, the organizations to denote their capacity to withstand the constraints and to maintain steady growth in the long future without compromising the present demands.

Sustainability as a key theme in the development arena can be understood best with the Brundtland Commission's (1987) definition. The Brundtland Commission, formally known as the World Commission on Environment and Development (WCED), was founded by the United Nations Commission on Environment and Development (UNCED) in 1984 to propose "a global agenda for change". The report of WCED, i.e., the Brundtland report (1987), laid the seed of the term "sustainability". It stated, "to make development sustainable-to ensure that it meets the needs of the present without compromising the ability of the future generations to meet their own needs" (United Nations, 1987, p.16). The introductory definition staged by the Brundtland Commission (1987) interprets sustainability in the realm of development, giving more emphasis on resource consumption, thus weighting the ecological perspective of sustainability. Guided by this definition, many even for the present only view sustainability from the environmental/ ecological lens, while few apply the concept across different economic and social themes. Yet, at present, the term has been branched into diverse fields, resulting in a broader construct with wider application. Despite immense theoretical and empirical support, the concept often encounters ambiguity in the interpretation and measure (Spangenberg, 2005; Arsic, Jovanović, Tomić, Tomović, Arsić, \& Bodolo, 2020; Vasiev, Denisov, $\mathrm{Bi}, \&$ Bocharnikov, 2020). Motivated by the aim of weeding off the interpretational anomalies, this paper reviewed the widespread definitions and measures of economic sustainability.

\section{THEORETICAL BACKGROUND}

The Brundtland report (1987) speculated environmental/ecological, economic, and social pillars as the dimensions of sustainability (United Nations, 1987). It assumes the equal contribution of three pillars to form sustainability (Figure 1). This falls into the early community development model, in which the three pillars are studied as separate disciplines. Hence, this opening thought of sustainability encouraged sectorial optimization of three individual systematic sectors

\footnotetext{
* Corresponding author: Tel.: +94 (71) 684 3285; Email: tennakoon@wyb.ac.lk

(D) https://orcid.org/0000-0001-6949-2048
} 
and ignored their interactive nature. Later, diverse theorizations ventured into alternative interpretations of the concept, resulting in equivocal understandings.

Figure 1. Three Pillars of Sustainability

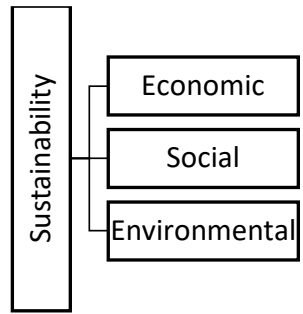

Source: Brundtland, G.H. (1987). Our Common Future. Oslo: The World Commission on Environment and Development (WCED) of United Nations.
The Triple Bottom Lines (TBLS) model of sustainability was proposed on par with the 3Ps; People, Planet, and Profit. Here, the TBLS are commonly identified as the key dimensions of sustainability (Elkington, 1994). They intend to measure the economic, environmental, and social aspects of any entity to assess sustainability (Figure 2). Elkington (1994, $1997,1998)$ argued the impossibility of achieving sustainability in any of the three dimensions in isolation. To him, only a parallel movement of three constructs would result in reaching a baseline for collective sustainability. That led his idea to label these three core constructs of sustainability as "triple bottom lines", as they serve as the foundation bricks of the sustainability core construct.

Figure 2. Triple Bottom Lines Model of Sustainability

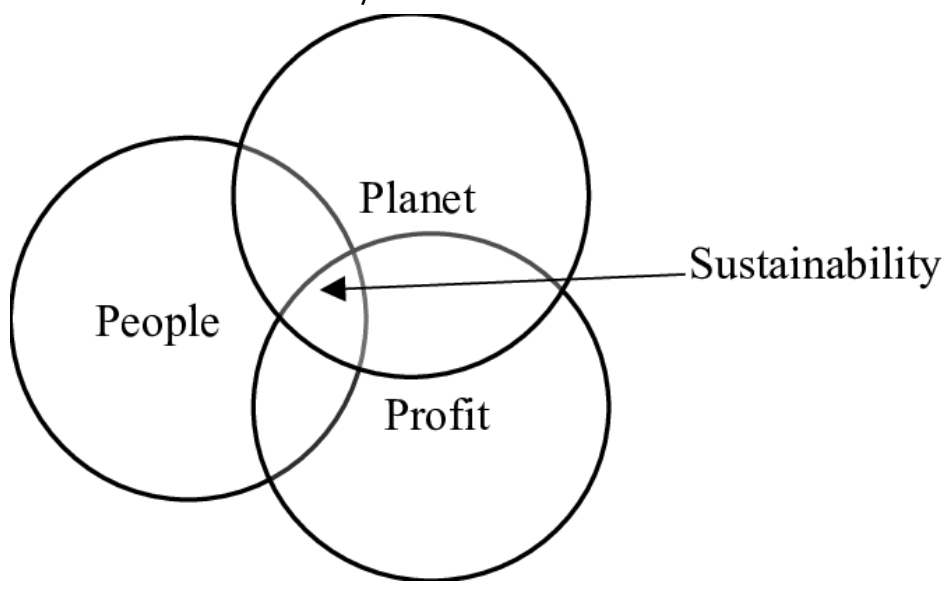

Source: Elkington, J. (1998). Partnerships from cannibals with forks: The triple bottom line of 21st-century business. Environmental Quality Management, 8(1), 37-51.

This is known as the popular sustainability theory, as many welcome the linkage between the environment, society, economy. Yet, this is also considered a weak model of sustainability, as the limited intersection area denoted a lesser possibility of reaching sustainability through the integrative approach. However, it doesn't account for the limitation imposed by the ecological dimension on the social and economic dimensions (Mulia, Behura, \& Kar, 2016). Despite the disagreement about the co-existing nature of Figure 3. Evolution of Sustainability models
TBLs, they are recognized as the uniform dimensions of sustainability in general.

The evolution of the sustainability models evident the movement from weak sustainability to strong sustainability. Importantly, regardless of the dependencies/ interactions, the number and the type of the dimensions remain identical across all categories of models (Figure 3 ). It is sound evidence of the wider acceptance of TBLs as the dimensions of sustainability.

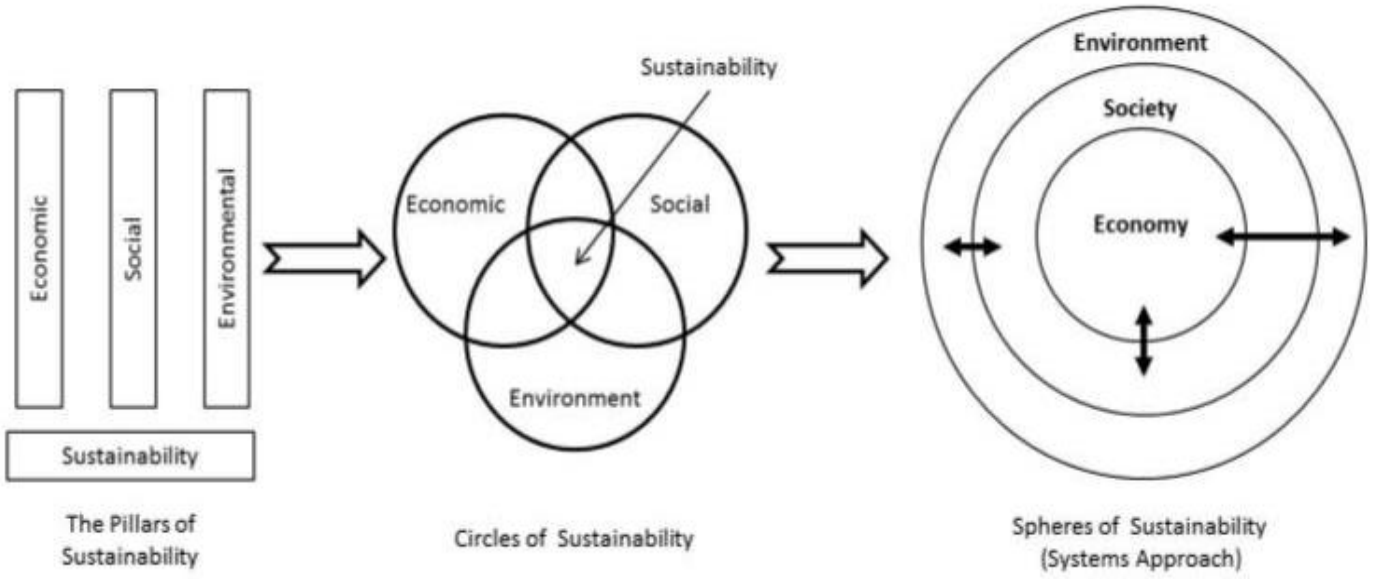

Source: Saharum, N., Songip, A. R., Habidin, N. F., \& Baroto, M. B. (2017). A Review of Evolutionary Theories in Sustainability related to the Franchise System. International Journal of Academic Research in Business and Social Sciences, 7(4), 756-771 
None of the constructs today possesses unilateral behavior because of the complexities of the dependencies among them. Hence, it is irrational to assume these systems are autonomous, thus they would not co-evolve. They essentially pose the potential for interactive behavior, so create a supersystem of sustainable development. Provided the inseparable behavior of three constructs, integration of these three dimensions for seeking sustainability is a timely concern. But many of those infatuated by financial motives ignore their interactive nature in development (Barron \& Gauntlett, 2002; Druva-Druvaskalne \& Livina, 2008; Bostrom, 2012; Husgafvel, et al., 2017; Ahmad, Muslija, \& Satrovic, 2021). Practically, it is seen that the economical demands have to be fulfilled primarily to gain ecological and social sustainability (Goldschmidt, Paiva, \& Irigaray, 2019; Ahmad, et al., 2021). Furthermore, among the three spheres of sustainability, economic sustainability appears fundamental once financing other spheres of sustainability (i.e. social and environmental) is concerned. For instance, shifting between low-cost non-biodegradable raw material and ecofriendly raw material in most cases is a matter of financing rather than a matter of motive towards sustainability. Hence, it is apparent that economic sustainability is leading the other spheres of sustainability (Ahmad, Muslija, \& Satrovic, 2021; Shmygol \& Kasianok, 2020; Jeswani, Whiting, \& Azapagic, 2020).

Next, the paper presents the method adopted in reviewing the prevailing literature of the construct.

\section{MATERIALS \& METHODS}

A desk review of the selected journal articles was performed. The selection criteria included the credibility of the article, measured against the number of citations and the credibility of the source, whether or not an indexed journal. An open time frame is considered where any article with significant academic merit is considered for the review regardless of its date of publication (oldest-1987, newest 2021). Resultantly, the final review was based on 322 research articles published in indexed journals of the leading e-databases, namely Emerald, JSTOR, OXFORD, EBSCO, Science Direct, and Taylor \& Francis. Additionally, the search of articles was performed in online journals of related disciplines. The search of articles is proceeded by three keywords, namely "definition"/ "defining", "measure"/ "measuring"/ "measurement", "economic sustainability". Each sifted article was reviewed against the others' work for denial and/ or ramification of anomalies among them. Qualitative throughputs of the review process are then presented in tabular form.

\section{RESULTS \& DISCUSSION}

Economic sustainability, one among the Triple Bottom Lines (TBLs), perhaps the most attractive and popular dimension of sustainability, is the long-term standpoint of an establishment in terms of financial and marketing measures. The realization of the value of economic sustainability is a far-felt need for practitioners because of its sense of stability.

The importance of assessing economic sustainability is emphasized by Jorgenson, Landefeld, \& Schreyer (2014) in their edited volume of "Measuring the economic Sustainability" which was a published volume from the National Bureau of Economic Research. They proposed economic sustainability as a remedy to cover up the gaps of inequalities of the income distribution, unsustainable trends in saving, spending, debt, housing, \& equity prices, the lack of data on health care, the environment, education \& human capital, and their increasing importance to the rate and sustainability of economic growth.

As quoted in Moddan et al. (2012, p. 5) the importance of economic sustainability is now increasingly recognized even by top political representatives. For instance, the former U.S. President Barrack Obama has stated: "It is simply not sustainable to have an economy where, in one year, 40 percent of our corporate profits came from a financial sector that was based on inflated home prices, maxed-out credit cards, over-leveraged banks, and overvalued assets". The contemporary uprising global economic crises thus call for a focus on the economic pillar and question the sustainability of development based on economic progress (Moldan, Janouskova, \& Hak, 2012). Redclift (1994) asserted perhaps some burning economic and social issues must first be addressed before environmental demands. For instance, poverty reduction is the primary goal of sustainable development, even before environmental quality can be fully addressed.

Economic sustainability eventually becomes the most attractive and popular dimension of sustainability, as it reflects the long-term standpoint of an establishment in terms of financial and marketing measures. Widespread use of the term as a core construct has amplified the variance among different definitions and accompanying measures. The next part of the paper dealt with presenting the reviewed definitions and indicators to uncover the avenues for broadening the existing theoretical understanding.

Economic sustainability, the center of the article's focus, is next reviewed for its definitions and measures based on the existing theoretical background.

\subsection{Defining Economic Sustainability}

Economic sustainability, as a principal element of sustainability, has been defined by several scholars from varied perspectives. Yet, a consensus over a universal definition has not been reached so far. Definitions of economic sustainability are presented hereinafter.

Based on Seguin and Germain's (2000) argument, economic sustainability is fundamental to social sustainability, which invites a basic level of financial resources to serve the members' needs of the society. The economic perspective of sustainability emphasis sustaining all kinds of "capitals"; manmade, natural, human, and social (World Bank, 2006).

Hungover, et al. (2017) while attempting to develop a uniform measure for economic and environmental aspects of sustainability, defined economic sustainability as the longterm competitiveness, profitability, and meeting the demands of shareholders. From a financial standpoint, an economic unit must be capable enough of satisfying the longterm demands of the shareholders. Competitiveness and profitability go hand in hand with the satisfaction of needs. However, generalization of these themes to the macro level, for example, to a government/ country may be a little controversial. Societal demands are usually deserved first place on top of pure economic measures. Thus, the reality reflects a socio-economic setup rather than a unified financial setting.

This mutually inclusive nature of societal, ecological, and economic dimensions of sustainability was well recognized in Morelli's interpretation of economic sustainability. He stated, "Economic sustainability should involve analysis to minimize the social costs of meeting standards for protecting environmental assets but not for determining what those standards should be" (Morelli, 2011). He demarcated 
the role of economic sustainability from the other two pillars, whereas economic sustainability is supposed to minimize the social cost of preserving the environment. This neither specifies the time dimension nor the target group, thus it reasonably encounters the larger community.

Sachs (1999) defined economic sustainability as the efficiency of economic systems (institutions, policies, and rules of functioning) to ensure continuous socially equitable, quantitative, and qualitative progress. Nevertheless, Sachs(1999) recognized the merge between social and economic dimensions, no environmental elements were incorporated. Yet, it holds the specialty of addressing both quantitative and qualitative aspects of economic progress. In a more general way, Harris \& Goodwin (2001) put it as a system able to produce goods and services continuously. This is an open expression of the ultimate aim of an economic system. Other than that, they emphasize the continuous nature of the supply, no added sustainable elements are presented.

The University of Mary Washington (2009) in their sustainability policy refers to economic sustainability as the practices that support long-term economic growth without affecting social, environmental, and cultural aspects of the community. In the meantime, they emphasize sustainable practices should be long-lasting and should cohabit with the social, environmental, and cultural aspects harmoniously. Similarly, Roderick G. Eggert (2002) in his contribution to the report of Mining, Minerals and Sustainable Development (MMSD) project of the International Institute for Environment and Development (IIED) has questioned the factual meaning of the term "sustainable" and/or "sustainable development". For him, it is maintaining something at the present level. Hence, economic sustainability would be to maintain the economic well-being at its current level. He further acknowledged the necessity to maintain TBLs simultaneously, i.e. enhance economic well-being, the quality of the natural environment, and social justice. Economic sustainability is achieving desired economic wellbeing without diminishing the environmental quality and in a socially justifiable manner (IIED, 2002). Here, the optimization of one element has been made impossible without satisfying the requirements of the other two elements.

Goerner, Lietaer, \& Ulanowicz (2009) viewed sustainability as the optimal balance of efficiency and resilience as determined by nature and measured by system structure. Efficiency is using fewer resources to satisfy more needs. Resilience is the ability to withhold despite obstacles and bounce back from a severe setback. Even though resource consumption is already a welcome theme of sustainability, resilience is a novel inclusion to the sustainability of systems. A similar idea was pointed out by Lien, Hardaker \& Flaten in 2007. As for them, an individual firm must remain financially viable in the meantime, providing an acceptable livelihood for the members.

Economically driven development has always been questioned for its sustainability. Hence, to be referred to as "sustainable", any economic progress should essentially couple with environmental and social deliverables. As such, an economic sustainability indicator couldn't be merely an economic metric (Moldan, et al., 2012). Maintaining economic growth is an essential and universally accepted objective for the broad public, compelling all policy makers to prioritize it top of all other demands. This itself creates it hard to maintain the balance between three pillars. Based on this line of thought, it is suggested to imaging a healthy economy ("a sustainable") without chasing economic growth targets.
However, along with the patterning economic crises, the need for a new economic setup within the frame of sustainable development is required. Pitelis (2013) claimed economic sustainability as value creation. Economics to be sustainable is expected to align with corporate governance, public and supra-national governance to form a worldwide novel economic system. At the junction of economic development, Pitelis's insights appear to be extremely relevant and timely due to the conflicting interest of economic growth and economic sustainability as suggested by Moldan et al. (2012).

While interpreting sustainability in economic terms, Stavins and colleges (2002) justified why the economists focus on the efficiency element in their journey towards sustainability, leaving equity considerations to the political process. They argued the insufficiency of dynamic efficiency itself to reflect sustainability (Stavins, Wagner, \& Wagner, 2002). Intergenerational equity is proposed to merge with dynamic efficiency to balance the need satisfaction level across generations: meeting the needs of both present and future generations. As they viewed, a sustainable growth path is both dynamically efficient and which is non-decreasing over time. Economic sustainability in the enterprise context is recently viewed by Shmygol \& Kasianok (2020) as the ability of an enterprise to develop dynamically under the influence of external and internal environments while maintaining all production and economic indicators. They criticize the recent developments in the sustainability context, for they overwhelm emphasis on the financial aspect, whereas for them, sustainability is a generic complex category that can't be limited to only one aspect of an entity. They claim the multifaceted and interconnected nature of the external and internal dynamic factors. Again, they account for the premises of the theory of stability of enterprises which makes essential the achieving of economic sustainability by an economical entity. Finkbeiner, Schau, Lehmann \& Traverso (2010) too introduced internal and external factors influencing the economic sustainability of a company. Likewise, many others have accepted the multidimensionality of the economic dimension of sustainability. Among the other scholars, who emphasize economic sustainability, Arsic, et al. (2020), Rezaee (2018), and Lopez-Perez, Melero_Polo, Vazquez_Carrasco, \& Cambra_Fierro (2018) were highlighting the importance of financial achievements (measured against the financial statements) of SMEs to reach the sustainability. Doane, \& Macgillivray (2001) stressed the elusiveness of economic sustainability as compared to the other two components of the TBL approach. In particular, to the SME context, Doane, \& Macgillivray (2001) put it as the effectiveness of assets within a business to allow and ensure its short-term profitability and long-term survival while Cantele \& Zardini (2018) high pointed the strategic-criticalness of economic sustainability, which is often grasped through sharpened market competitiveness.

Definitions discussed so far more or less reflected a mix of socio-economic and ecological aspects rather than pure economic measures. In a way, this is acknowledging the desired harmonious evolution of the three spheres. A summary of reviewed definitions is presented in table 1.

The Seven level models of personal and organizational consciousness (Boyd-Barrett, 1998) recognized "survival" as the basic need for both individuals and institutions. For individuals, it is physical survival \& safety and for organizations, it is financial stability. Hence, it can be reasonably argued that 
the glimpses of sustainability in the SME context thus originate from the economic sustainability (i.e. financial stability) as expected by both the owner (individual) and the business (organization). Consequently, the present study defines economic sustainability as the ability to remain financially viable Table 1. Summary of Definitions - Economic Sustainability while providing an acceptable level of life-hood to its stakeholders.

\begin{tabular}{|c|c|}
\hline Author/s & Definition \\
\hline $\begin{array}{l}\text { Borgonovi \& Conpagin, } \\
\text { (2013) }\end{array}$ & $\begin{array}{l}\text { Economic sustainability means devising better ways to assess what is critical, defining pri- } \\
\text { orities in the allocation of resources, and, simply, getting the most out of health care sys- } \\
\text { tems }\end{array}$ \\
\hline $\begin{array}{l}\text { Doane \& Macgillivray, } \\
\text { (2019) }\end{array}$ & $\begin{array}{l}\text { An effective use of assets within a business to allow and ensure its short-term profitability } \\
\text { and long-term survival. }\end{array}$ \\
\hline Goerner et al, (2009) & $\begin{array}{l}\text { The optimal balance of efficiency and resilience is determined by nature and measured by } \\
\text { system structure. }\end{array}$ \\
\hline $\begin{array}{l}\text { Guth, Smedzik-Ambrozy, } \\
\text { Czyzewski, \& Stepien, } 2020\end{array}$ & $\begin{array}{l}\text { Economic sustainability (or socio-economic sustainability if we assume that income ine- } \\
\text { qualities are part of social sustainability), can be seen in terms of the income gap between } \\
\text { agricultural and non-agricultural sectors. }\end{array}$ \\
\hline Harris \& Goodwin, (2001) & A system able to produce goods and services on a continuing basis. \\
\hline Husgafvel, et al., (2017) & $\begin{array}{l}\text { Is about long-term competitiveness, profitability, and meeting the demands of sharehold- } \\
\text { ers }\end{array}$ \\
\hline IIED, (2002) & $\begin{array}{l}\text { Economic sustainability is achieving desired economic well-being without diminishing the } \\
\text { environmental quality and in a socially justifiable manner. }\end{array}$ \\
\hline Lien et al., (2007) & Remain financially viable while providing acceptable livelihood \\
\hline Morelli, (2011) & $\begin{array}{l}\text { Economic sustainability should involve analysis to minimize the social costs of meeting } \\
\text { standards for protecting environmental assets, but not for determining what those stand- } \\
\text { ards should be }\end{array}$ \\
\hline Pitelis, (2012) & Economic sustainability as a value creation \\
\hline Rezaee, (2018) & $\begin{array}{l}\text { Economic sustainability or business sustainability is about creating a proper balance of } \\
\text { short- and long-term continuous improvement of both financial Economic Sustainability } \\
\text { Performance (ESP) and non-financial Environmental, Ethical, Social and Governance (EESG) } \\
\text { sustainability performance. }\end{array}$ \\
\hline Sachs, (1999) & $\begin{array}{l}\text { The efficiency of economic systems (institutions, policies, and rules of functioning) to en- } \\
\text { sure continuous socially equitable, quantitative, and qualitative progress }\end{array}$ \\
\hline $\begin{array}{l}\text { Shmygol \& Kasianok, } \\
(2020)\end{array}$ & $\begin{array}{l}\text { The ability of an enterprise to develop dynamically under the influence of external and } \\
\text { internal environments, while maintaining all production and economic indicators }\end{array}$ \\
\hline Spangenberg, (2005) & $\begin{array}{l}\text { A sustainable economy must not undermine the sustainability of the systems it is interact- } \\
\text { ing with (population, society, the natural environment, and other economies) while de- } \\
\text { fending its viability }\end{array}$ \\
\hline Stavins et al., (2002) & Economic sustainability is dynamic efficiency plus intergenerational equity \\
\hline $\begin{array}{l}\text { The University of Mary } \\
\text { Washington, (2009) }\end{array}$ & $\begin{array}{l}\text { Economic sustainability refers to the practices that support long-term economic growth } \\
\text { without negatively affecting social, environmental, and cultural aspects of the community }\end{array}$ \\
\hline
\end{tabular}

The Seven level models of personal and organizational consciousness (Boyd-Barrett, 1998) recognized "survival" as the basic need for both individuals and institutions. For individuals, it is physical survival \& safety and for organizations, it is financial stability. Hence, it can be reasonably argued that the glimpses of sustainability in the SME context thus originate from the economic sustainability (i.e. financial stability) as expected by both the owner (individual) and the business (organization). Consequently, the present study defines economic sustainability as the ability to remain financially viable while providing an acceptable level of life-hood to its stakeholders.

This review aimed at assessing the suitability of economic sustainability measures in the light of what they intend to measure. Dimensions of economic sustainability fall into a wider range, causing it to be difficult to develop a uniform measure of the construct. Dimensions of economic sustainability, as developed by previous scholars, are reviewed next.

\subsection{Measures of Economic Sustainability}

Many dimensions based on previously discussed definitions are presented and reviewed hereinafter.
The strong sustainability model claims environmental sustainability as the core within which economic and social sustainability lies (Figure 3). Weak sustainability models hint at the mutual existence of three spheres. Two schools of models, however, posit that no pure individual dimension can be optimized without acknowledging the progress of the rest of the dimensions. Following this generalization, many, if not all, theoretical frameworks presented so far attempted to incorporate more or less social and environmental elements in assessing economic sustainability.

Husgafvel, et al. (2017) identified, tested, and finalized nine dimensions of economic sustainability. They utilized an integrative approach of joint consultation of the university and the metal industry in developing the measures while they were tested based on two hypothetical cases. The dimensions/indicators include key financial statistics, investments, raw materials \& energy, risks, supply chain, social aspects, cross effects, cost based on legislation, and legal aspects (Husgafvel, et al., 2017). On average, these dimensions sheltered a wider range of economic and operational activities of an organization. Importantly, they identified legal and social aspects too in measuring the economic well-being of an institute. 
Narrowing the economic sustainability in farm production, Christen \& Dalgaard (2013) figured out four dimensions namely; cost efficiency, food production, energy production, and investments. The incorporation of the environmental and social dimensions in the economic measures is a property of Christen \& Dalgaard's framework of economic sustainability. However, this may not compatible well across diverse industrial set-ups due to industry-specific characteristics. A practical yet representative measure is proposed by Sachs (1999) combining environmental and economic indices. Therein, fixed \& variable cost components and environmental cost elements are joined to reflect the economic sustainability. Having environmental cost included in the economic measure is a strength of the model, while the absence of a social cost element can be viewed as a limitation. Some scholars pointed out the avenue for accounting, social cost in the fixed and variable cost themselves (Assefa \& Frostell, 2007). Nevertheless, for many industries, this model fitted well in balancing quantitative and qualitative progress.

A macro-level assessment of economic sustainability calls for evaluating the economic viability of governing systems. Harris \& Goodwin (2001) incorporated government debt, external debts, and sectoral imbalances as the determinants of economic sustainability of a government/an economic system/a country. But, they have given no/little emphasis on linking social and environmental dimensions with it. Further, sectorial imbalances would have been specified operationally to overcome the possible implicational limitations.

The sustainability principle of the University of Mary Washington (2009) identified four aspects as predictors of economic sustainability. They are environmental, cultural, social, and economic aspects. Multidimensionality that allows merging many indicators is a merit of this conceptualization. However, in this way, "sustainability" and "economic sustainability" make little difference. Another classification theorized resilience and efficiency of the system as measures of economic sustainability. Using the provisions of free-enterprise theory, Goerner et al. (2009) argued resilience and efficiency as the most essential, yet complementary factors that ensure economic viability. Furthermore, they distinguished economic sustainability from economic growth using mathematical modeling. Rigamonti, Sterpi \& Grosso in 2016 viewed cost as the principal dimension of economic arms of sustainability. They aimed at defining a clear and comprehensive indicator to evaluate the environmental and economic sustainability of an integrated waste management system. The suggested composite indicator has three elements; two for environmental assessment (Material Recovery Indicator [MRI], and Energy Recovery Indicator [ERI] and one for economic assessment (Cost Indicator [CI]). As they have tailored it to the municipal waste management system, the cost of collection, the cost of treatment, and the cost of final disposal were the dimensions reflecting economic sustainability. For a waste management system, the cost would serve as the major, but not the only indicator of all financial substances. Importantly, a waste management system should account for the financial burden of social costs associated with handling the waste in an environmentally amenable way. They admitted the limitation of not including the societal element thus suggested as a prospective development.

The sustainability dialogues often centered on the needed satisfaction of both present and future generations (Brundtland, 1987; Bansal \& DesJardine, 2014; Malesios, et al., 2018; Husgafvel, et al., 2017). Stavins and his colleagues
(2002) counted this principle in assessing economic sustainability and claimed intergenerational equity as one of two dimensions of economic sustainability. The other was dynamic efficiency. They held that efficiency itself is insufficient in assessing the economic sphere of sustainability and shouldn't leave "equity" to be handled through a political arm. Alternatively, they proposed linking both efficiency and equity to form a normative interpretation of economic sustainability. Stavins et al. were the first to count equity to represent social dimensions within an assessment of economic sustainability.

The industry/sector-specific indicators are very common in the arena of economic sustainability. Importantly, the energy sector and agriculture have received greater attention from scholars. In environmental management, the production and use of biomass are hot topics. Hanegraaf, Biewinga, \& Bijl (1998) adopted a tri-dimensional model for assessing the economic sustainability of energy crop production. Their method for assessing ecological and economic sustainability of energy crops used 12 ecological criteria and 3 economic criteria. The proposed criteria analysis involved the cost price of energy produced, costs of abated $\mathrm{CO} 2$ emission, and employment creation per hectare. The first and the last denoted the general economic measures while the second sheltered the specific economic measure of assessing the sustainability of all three criteria. Addressing the lifecycle of energy crop production is a strength of this model. However, any of these three criteria doesn't explicitly address the socio-economic aspect, whereas it was already a generalized facet of economic well-being.

Pieper (1999) interpreted labor productivity and productivity growth as the dimensions/indicators of economic sustainability. Labour, the most critical factor of production, may account for a considerable portion of the economic behaviour of an entity. However, it is inadequate to represent the overall economic well-being of the entire community as required for a sustainable economy. On the other hand, productivity growth would indicate the macro-economical gain but not the social dimension of sustainability.

Vasiev, Bi, densov, \& Bocharnikov (2020) in assessing the COVID-19 pandemic impact on Chinese economic sustainability, used a combination of micro and macro indicators to measure the economic sustainability. Apart from the indicators directly addressing the economical stand of an entity, they have considered energy efficiency rating, energy consumption, and technological efficiency ratings as the measures of economic sustainability. Yet, these indicators have been traditionally used by many scholars as to the measures of environmental sustainability (Husgafvel, et al., 2017; Lawrence, et al., 2006). Any measure of economic sustainability generally aims to account for the monetary dimension of environmental protection. Hence, the inclusion of the cost of environmental protection within the economic sustainability measures is theoretically justifiable. On contrary, a double accounting risk may arise such that the same cost element may be accounted for in both environmental and economic sustainability dimensions resulting in fake inflation of the total cost of sustainability.

Guth et al. (2020) used the income gap ratio to measure economic sustainability while analyzing the economic sustainability of farms under a common agricultural policy in the European Union. Here, a single direct economic indicator is used to assess economic conditions. It may not be appropriate to reach an acceptable level of internal validity. In contrast to that, Jeswani, Whiting, \& Azapagic 
(2020) have used a set of indicators of diverse economical aspects to quantify economic sustainability. This portfolio of indicators is referred to as the Life Cycle Costs of economic sustainability and covers almost all the forms of financial expenditure related to environmental protection. Similarly, Kargbo, Harris, \& Phan (2021) used Life Cycle Analysis in which the cost of biomass cultivation, harvesting, biomass Table 2. Summary of Dimensions-Economic Sustainability

Author/s
Assefa \& Frostell (2007)

Authority of the Minister of Health, (2012)

Carew \& Mitchell (2002)

Christen et al, (2013)

Finkbeiner, (2010)

Food and Agricultural Organization of United Nations, (2017)

Goerner et al, (2009)

Guth, Smedzik-Ambrozy, Czyzewski, \& Stepien (2020) Hanegraaf, (1998)

Harris \& Goodwin (2001)

Husgafvel, et al. (2017)

Jeswani, Whiting, \& Azapagic (2020)

Kargbo, Harris, \& Phan (2021)

Laininen, Manninen, \& Tenhunen, (2006)

Pieper, (1999) pre-treatment, and transportation were the readers of economic sustainability.

Likewise, the different authors have used numerous types of dimensions in assessing the economic sustainability of which the summary is presented in table 2 .
Dimension/s

Variable cost

Environmental cost

Income

Employment

Working Conditions

Business Imperative

Appropriate design

Changing the development paradigm

Cost efficiency

Food production

Energy production

Investments

Cost

External economic criteria

Internal economic criteria

Profits

Jobs/Incomes

Tax revenues

Food Supply

Resilience

Efficiency

Income gap ratio

The cost price of energy produced

Costs of abated $\mathrm{CO}_{2}$ emission

Employment creation per hectare

Government debt

External debt

Sectoral imbalances

Key Financial Statistics

Investments

Raw materials, energy

Risks

Supply chain

Social aspects Etc.

Cross effects

Cost based on legislation

Legal aspects

1. Life Cycle Costing (Hunkeler et al., 2008; Swarr et al., 2011)

Capital cost

Gross lifetime (20 years) operating costs

Gross lifetime cost without RHI

Lifetime RHI

Lifetime cost with RHI

Gross cost without RHI

Average RHI traiff

Net cost with RHI

Payback time when replacing

Life Cycle Analysis (LCA)

Economy. eco-efficiency and lifecycle of products

Use of fair trade products

Real estate maintenance

Optimization of transports

Mult-use premises

Labour productivity

Productivity growth 
Rigamonthi et al., (2016)

Rodriguez, et al., (2002)

Sachs (1999)

Spangenberg, (2005)

Stavins et al. (2002)

United Nations, (2015)

The University of Mary Washington, (2009)

Vasiev, Bi, densov, \& Bocharnikov (2020)

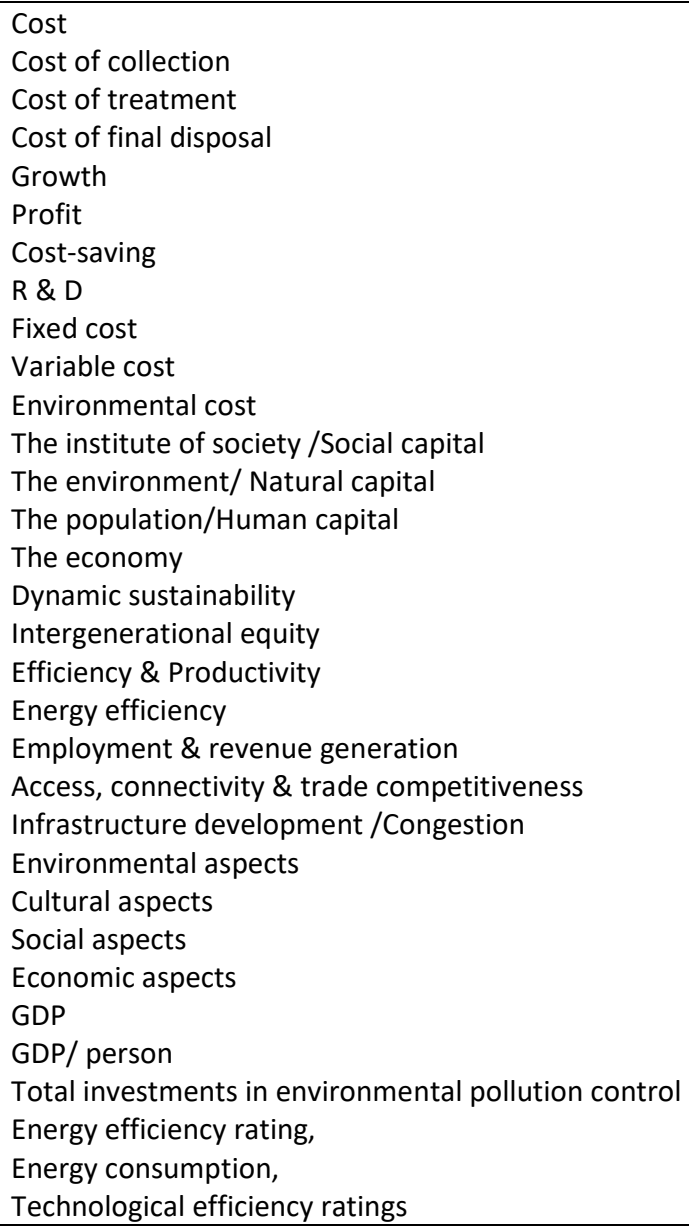

Many conceptualized economic sustainability about different industries/ disciplines (Husgafvel, et al., 2017; Christen, et al., 2013; Rigamonti, Sterpi, \& Grosso, 2016; Hangraaf \& Biewinga, 1998). Some theoretical frameworks are however can be generalized into different levels/entities of the economic system (Sachs, 1999; Harris \& Goodwin, 2001; Assefa \& Frostell, 2007; Goerner, et al., 2009; Carew \& Mitchell, 2002; Spangenberg, 2005; Pieper, 1999; Guth, et al., 2020).

Boyd-Barrett's seven-level model of organizational consciousness (1998) posits the necessity of any entity to survive before it seeks the realization of high-order goals. The economic indices for a for-profit organization are the prime determinant of its existence. Based on this premise, one can rationalize thinking of economic sustainability as the foremost aim, while the other two arms will eventually become the subsequent targets. Unur, Sker \& Kale (2017) highlighted that economic gains jeopardize environmental and socio-cultural factors in the journey towards sustainability. Seguin and Germain (2000) also felt that economic sustainability is fundamental to social sustainability, as social sustainability is financially fueled by economic sustainability. As such, the sustainable environmental and social behaviour of an entity is permitted only after they achieve a satisfactory level of financial stability (Boyd-Barrett, 1998, 2006). In short, simply "money" comes first in many decision scenarios, irrespective of how rational the other alternatives are.

Further, Freeman's stakeholder theory (1984) as cited in Freeman (1999) and Jensen's Enlightened value maximization theory (2000) recognized the maximization of sustainable performance of a firm to satisfy the demands of stakeholders and to maximize the value they can enjoy. As cited by Polonsky (1995), Jensen (2000) commented on how the firm should create value to balance the interests of internal and external stakeholders. The interests of stakeholders most of the time resemble the financial metrics. Hence, optimizing economic sustainability is central to the rest of the sustainability extents.

Accordingly, the sustainable performance models that prioritized economical sustainability over the rest of the sustainable dimensions are relatively high in their ability to assess the actual sustainable performance of the organizations.

\section{CONCLUSION}

This review aimed at revisiting the measures of economic sustainability considering the ultimate aim of such measures to assess the financial testament of sustainability achievements. The desk review of prevailing contributions by leading theorists demonstrates dimensions of a wider range, particularly varied based on the industries where they have adopted. This has made the theoretical construct of economic sustainability a complex one to adopt for assessing the same of any entity, regardless of their sector. Building on the premises of a strong sustainability model, many economic sustainability theoretical frameworks presented so far attempted to incorporate more or less social and environmental elements in assessing economic sustainability. Given the mutually exclusive nature of the three spheres of sustainability, it can be theoretically admissible. Hence, the development of any uniform measure of economic sustainability is expected to incorporate glimpses of the other two dimensions of sustainability as well. The incorporation of social well-being indicators in the economic sustainability 
frames is hardly evident despite the economic sustainability usually going hand in hand with the social well-being of the parties involved. Therefore, it is suggested for future donors to integrate social well-being flavours (For instance, legal and social aspects) in the economic dimension of sustainability. Based on the review results that witness the limited application of the measure across a wider range of contexts, it is advisable to avoid the extreme level of specification of the dimension in diverse industry contexts. For instance, the dimensions adopted by Christen et al. (2013) for farm production nor the dimensions used in the metal industry by Husgafvel, et al. (2017) may not be ideally fitting with another organizational setup with distinctive features. Additionally, it is noted that most dimensions proposed by many scholars are not directly related to the financial aspect of sustainability. Thus, often are ambiguous with the rest of the two dimensions of sustainability: social and environmental. Principally, economic sustainability measures were found hard to distinguish from the environmental sustainability dimensions. This is also counted as an issue that lies in the hands of future research on the discipline. Context-specific /industry-centric measures are frequently reported, which, as per the authors' view, has unnecessarily intensified the breadth of the construct, limiting its application to few comparable contexts. A simple yet reflective measure will always poster the application of the measure. Not only, such measures will be high in internal and external validity, but also they tend to show greater flexibility in application across a varied range of contexts. For instance, Sachs's classification (1999) includes fixed cost, variable cost, and environmental cost to quantify economic sustainability. There, fixed $\&$ variable cost components and environmental cost elements are joined to reflect the economic sustainability. Inclusion of environmental cost is considered a merit of this measure, while the exclusion of a social cost element can be viewed as a demerit. Nevertheless, future work on this connection is expected to address these conceptual equivocalities. Furthermore, it is advisable to form measures of a signal level where multiple units of analysis in the same conceptual fam would result in interpretational complications. The majority of sustainability and economic sustainability measures don't clearly distinguish each other. Yet, being two main core constructs, maintaining clear separable dimensional properties for distinct operationalization of two constructs is of utmost importance. Finally, the authors are of the view that any measure of economic sustainability should be essentially multi-dimensional but not uni-dimensional accounting for the widespread nature of the construct. These proposed theoretical commands in developing a uniform yet the general measure of greater external \& internal validity and higher operational flexibility are considered the implications for impending contributions.

\section{REFERENCES}

Ahmad, M., Muslija, A., \& Satrovic, E. (2021). Does economic prosperity lead to environmental sustainability in developing economies? Environmental Kuznets curve theory. Environmental Science and Pollution Research, 1-14.

Arsić, M., Jovanović, Z., Tomić, R., Tomović, N., Arsić, S., \& Bodolo, I. (2020). Impact of logistics capacity on economic sustainability of SMEs. Sustainability, 12(5), 1911.

Assefa, G., \& Frostell, B. (2007). Social Sustainability and social acceptance in technology assessment: A case study of energy technologies. Technology in Society, 29, 63-78.

Authority of the Minister of Health. (2012). Planning for a Sustainable Future: Health Canada's 2011-2014 Sustainable Development Strategy. Ontario: Health Canada Publications.
Bansal, P., \& DesJardine, M. R. (2014). Business sustainability: It is about time. Strategic Organization, 12(1), 70-78. doi:DOI: $10.1177 / 1476127013520265$

Baroon, L., \& Gauntlet, E. (2002). Housing and Sustainable Communities Indicators Project. The Regional Institute.

Borgonovi, E., \& Compagni, A. (2013). Sustaining universal health coverage: The Interaction of social, political and economic sustainability. Value in Health, 16, 534-538.

Bostrom, M. (2012). 'A missing pillar? Challenges in theorizing and practicing social sustainability: Introduction to the special issue'. Sustainability: Science, Practice and Policy, 8(1), 3-14.

Boyd-Barrett, O., \& Rantanen, T. (Eds.). (1998). The globalization of news. Sage.

Brundtland, G. H. (1987). Our Common Future. Oslo: The World Commission on Environment and Development of United Nations.

Cantele, S., \& Zardini, A. (2018). Is sustainability a competitive advantage for small businesses? An empirical analysis of possible mediators in the sustainability-financial performance relationship. Journal of Cleaner Production, 182, 166-176.

Carew , A. L., \& Mitchell, C. A. (2002, September ). Teaching sustainability as a contested concept: Capitalizing on variation in engineering educators' conceptions of environmental, social and economic sustainability. Australian Association for Engineering Education's 13th Annual Conference.Canberra, Australia:

Christen, B., \& Dalgaard, T. (2013). Buffers for biomass production in temperate European agriculture: A review and synthesis on function, ecosystem services, and implementation. Biomass and Bioenergy, 55, 53-67.

Doane, D., \& MacGillivray, A. (2001). Economic sustainability: The business of staying in business. New Economics Foundation, 1-52.

Druva-Druvaskalne, I., \& Livina, A. (2008). Development of the Sustainable Development Profile for the North Vidzeme Biosphere ReserveFinal Report-Summary.

Elkington, J. (1994a). Enter the Triple Bottom Line. In J. Elkington.

Elkington, J. (1994b). Towards the Sustainable Corporation: Win-WinWin Business Strategies for Sustainable Development. California Management Review, 36(2), 90-100.

Elkington, J. (1998). Partnerships from cannibals with forks: The triple bottom line of 21st-century business. Environmental Quality Management, 8(1), 37-51.

Elkington, J. (1999). Cannibals with Forks: Triple Bottom Line of 21st Century Business. John Wiley \& Son Ltd.

Freeman, R. E. (1999). Divergent stakeholder theory. Academy of management review, 24(2), 233-236.

Finkbeiner, M., Schau, E.M., Lehmann, A., Traverso, M.(2010). Towards Life Cycle Sustainability Assessment. Sustainability, 2(10), 33093322.

Food and Agricultural Organization of United Nations. (2017). ClimateSmart Agriculture Sourcebook. Geneva: United Nations.

Goerner, S. J., Lietaer, B., \& Ulanowicz, R. E. (2009). Quantifying economic sustainability: Implications for free-enterprise theory, policy, and practice. Ecological Economics, 69, 76-81.

Guth, M., Smędzik-Ambroży, K., Czyżewski, B., \& Stępień, S. (2020). The economic sustainability of farms under common agricultural policy in the European Union countries. Agriculture, 10(2), 34.

Goldschmidt, C. C., De Paiva, K. C. M., \& Irigaray, H. A. R. (2019). Organizational resilience: a proposal of an integrated model and research agenda. Tourism \& Management Studies, 15(3), 37-46.

Hanegraaf, M. C., \& Biewinga, E. E. (1998). Assessing the ecological and economic sustainability of energy crops. Biomass and Bioenergy, 15(4-5), 345-355.

Harris, J. M., \& Goodwin, N. R. (2001). Introduction. In M. H. Jonathan, A. W. Tomothy, P. G. Kevin, \& R. G. Neva, A survey of Sustainable development: Social and economic dimensions, Frontier issues in economic thought, 6. Washington: Island Press.

Husgafvel, R., Pajunen, N., Dahl, O., Heiskanen, K., Ekroos, A., \& Virtanen, K. (2017). Development of Environmental and Economic Sustainability Metrics for the Metal Production Industry-Experiences From University-Industry Cooperation. Sustainable Business, Management, and Economics, 2, 98-122. 
IIED. (2002). Mining and Economic Sustainability: National Economies and Local Communities. UK: Mining, Minerals and Sustainable Development (MMSD).

Jensen, M. C. (2000). Value maximization and stakeholder theory. Harvard Business School Working Knowledge. July, 24.

Jeronen, E. (2013). Sustainability and sustainable development. In S. O. Idowu, N. Capaldi, L. Zu, \& A. D. Gupta, Encyclopaedia of corporate social responsibility (p. 88). Berlin, Heidelberg: Springer.

Jeswani, H. K., Whiting, A., \& Azapagic, A. (2020). Environmental and economic sustainability of biomass heat in the UK. Energy Technology, 8(11), 1901044

Jorgenson, W. D., Landefeld, S. J., \& Schreyer, P. (2014). Introduction to "Measuring Economic Sustainability and Progress". In W. D. Jorgenson, S. J. Landefeld, \& P. Schreyer (Eds.), Measuring Economic Sustainability and Progress (pp. 1-16). Chicago: University of Chicago Press.

Kargbo, H., Harris, J. S., \& Phan, A. N. (2021). "Drop-in” fuel production from biomass: Critical review on techno-economic feasibility and sustainability. Renewable and Sustainable Energy Reviews, 135, 110168

Laininen, E., Manninen, L., \& Tenhunen, R. (2006). Näkökulmia kestävään kehitykseen oppilaitoksissa. OKKA-säätiö, Helsinki.

Lawrence, S., Collins, E., Pavlovich, K., \& Arunachalam, M. (2006). Sustainability Practices of SMEs: the Case of NZ. Business Strategy and the Environment, 15, 242-257. doi:DOI: 10.1002/bse.533

Lien, G., Hardaker, J. B., \& Flaten, O. (2007). Risk and economic sustainability of crop farming systems.

López-Pérez, M. E., Melero-Polo, I., Vázquez-Carrasco, R., \& Cambra-Fierro, J. (2018). Sustainability and business outcomes in the context of SMEs: Comparing family firms vs. non-family firms. Sustainability, 10(11), 4080.

Malesios, C., Skouloudis, A., Dey, P. K., Abdelaziz, F. B., Kantartzis, A., \& Evangelinos, K. (2018). Impact of small-and medium-sized enterprises sustainability practices and performance on economic growth from a managerial perspective: Modeling considerations and empirical analysis results. Business strategy and the environment, 27(7), 960-972.

Moldan, B., Janouskova, S., \& Hak, T. (2012). How to understand and measure environmental sustainability: Indicators and targets. Ecolog ical Indicators, 17, 4-13.

Morelli, J. (2011). Environmental Sustainability: A Definition for Environmental Professionals, 1(1).

Mulia, P., Behura, A. K., \& Kar, S. (2016). Categorical Imperative in Défense of Strong Sustainability. Problems of sustainable development $11(2), 29-36$

Pieper, U. (1999). Deindustrialization and the Social and Economic Sus tainability Nexus in Developing Countries: Cross-Country Evidence on Productivity and Employment. New York: Center for Economic Policy Analysis of New School for Social Research.

Pitelis, C. N. (2013). Towards a More 'Ethically Correct' Governance for Economic Sustainability. Journal of Business Ethics. doi:10.1007/s10551-012-1616-8

Polonsky, M. J. (1995). A stakeholder theory approach to designing an environmental marketing strategy. Journal of business \& industrial marketing.

Redclift, M. R. (1994). Reflections on the 'sustainable development' debate. International Journal of Sustainable Development, 1, 3-21.

Rezaee, Z. (2018). Supply chain management and business sustainability synergy: A theoretical and integrated perspective. Sustainability, 10(1), 275.

Rigamonti, L., Sterpi, I., \& Grosso, M. (2016). Integrated municipal waste management systems: An indicator to assess their environmental and economic sustainability. Ecological Indicators, 60, 1-7.

Rodriguez, S. I., Roman, M. S., Sturhahn, S. C., \& Terry, E. H. (2002). Sustainability assessment and reporting for the University of Michigan's Ann Arbor Campus. Centre for Sustainable Systems, Report No. CSSO2-04. University of Michigan, Ann Arbor, Michigan.

Sachs, I. (1999). Social sustainability and whole development: exploring the dimensions of sustainable development. In B. Egon, \& J. Thomas, Sustainability and the social sciences: A cross-disciplinary approach to integrating environmental considerations into theoretical reorientation. London: Zed Books.
Saharum, N., Songip, A. R., Habidin, N. F., \& Baroto, M. B. (2017). A Review of Evolutionary Theories in Sustainability related to the Franchise System. International Journal of Academic Research in Business and Social Sciences, 7(4), 756-771.

Seguin, A., \& Germain, A. (2000). The social sustainability of Montreal: a local or a state matter? In M. Polese, \& R. Stren, The Social Sustainability of Cities: Diversity and the Management of Change (pp. 39-87). Toronto, Buffalo, and London. : University of Toronto Press.

Shmygol, N., \& Kasianok, M. (2020). Analysis of financial and economic sustainability of enterprises based on the use of accounting and analytical instruments. The Scientific Journal of Cahul State University "Bogdan Petriceicu Hasdeu" Economic and Engineering Studies, 7(1), 29-35.

Spangenberg, J. H. (2005). Economic sustainability of the economy: concepts and indicators. International Journal Sustainable Development, $8(1 / 2), 47-64$

Stavins, R. N., Wagner, A. F., \& Wagner, G. (2002). Interpreting sustainability in economic terms: Dynamic efficiency plus intergenerational equity, Nota di Lavoro, 61

The University of Mary Washington. (2009). Sustainability policy. University of Mary Washington Strategic Plan. Fredericksburg, Virginia.

United Nations. (2015). Review of Maritime Transport. Geneva: United Nations.

Unur, K., Sker, F., \& Kale, A. (2017). Sustainability Definitions of Hotel Businesses. In Kızkalesi. The First International Congress on Future of Tourism: Innovation, Entrepreneurship, and Sustainability (pp. 361366). Mersin, Turkey: Tourism Faculty, Mersin University.

Vasiev, M., Bi, K., Denisov, A., \& Bocharnikov, V. (2020). How COVID-19 Pandemics Influences Chinese Economic Sustainability. Форсайт, 14(2 (eng)).

World Bank. (2006). Where is the Wealth of Nations? Measuring Capital for the 21st Century. Washington, D.C.: World Bank. 